\title{
Sodium monensin or propolis extract in the diets of feedlot-finished bulls: effects on animal performance and carcass characteristics
}

\author{
F. Zawadzki ${ }^{1}$, I.N. Prado, ${ }^{2,5}$ J.A. Marques ${ }^{3}$, L.M. Zeoula ${ }^{2}$, \\ P.P. Rotta ${ }^{1}$, B.B. Sestari ${ }^{1}$, M.V. Valero ${ }^{1}$ and D.C. Rivaroli ${ }^{1}$ \\ State University of Maringá, \\ ${ }^{1}$ Department of Animal Science - Science grant - CNPq, \\ ${ }^{2}$ Department of Animal Science \\ Av. Colombo, 5790 - CEP 87020-900 - Maringá, Paraná, Brazil \\ ${ }^{3}$ Federal University of Recôncavo of Bahia, Department of Animal Science \\ Bahia, Brazil
}

(Received 11 September 2009; revised version 2 February 2011; 12 March 2011)

\begin{abstract}
This study evaluates the effects of three diets: a control (CON), containing sodium monensin (MON) and containing propolis extract (PRO). The performance of 33 feedlot-finished bulls, 11 for each diet, and carcass characteristics were examined. The 27 months old bulls, with initial liveweight $400 \pm 2.33 \mathrm{~kg}$, were kept in a feedlot for 84 days, till $484 \pm 6.76 \mathrm{~kg}$ at slaughter. The roughage and concentrate ratio of the diets was 52:48 on DM basis. Maize silage was used as roughage and maize, soyabean meal, urea, mineral salt and limestone were used as concentrate. The average final weight $(501 \mathrm{~kg})$, hot carcass weight $(275 \mathrm{~kg})$ and average daily gain $(1.17 \mathrm{~kg})$ were higher $(\mathrm{P}<0.05)$ for bulls fed with PRO than for those on the CON $(472,259$ and $0.87 \mathrm{~kg}$, respectively), or MON $(480,259$ and $0.94 \mathrm{~kg}$, respectively) diets. Dry matter conversion was better $(\mathrm{P}<0.05)$ for bulls fed with PRO (8.04) than those on the CON (10.9) or MON (9.72) diets. Carcass characteristics such as conformation, carcass length, leg length, cushion thickness, Longissimus muscle area, Longissimus muscle area $/ 100 \mathrm{~kg}$ of liveweight, fat thickness, colour, texture and marbling were not influenced $(\mathrm{P}>0.05)$ by the treatments.
\end{abstract}

KEY WORDS: cattle, carcass, meat, propolis extract, sodium monensin

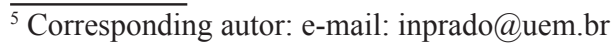




\section{INTRODUCTION}

Meat plays an important role in human diet, providing high quality protein (Rotta et al., 2009b), essential fatty acids (Maggioni et al., 2009; Rotta et al., 2009a,b), minerals and B-complex vitamins. However, red meat contains saturated fatty acids and cholesterol, and the consumption of these substances has been associated with a number of health problems, including cardiovascular disease, obesity, hypertension and cancer (Aricetti et al., 2008; Prado et al., 2009a,b,c). The presence of saturated fatty acids in beef is related to the biohydrogenation process that occurs in the rumen.

The livestock industry is continually searching for ways to minimize the feed costs involved in cattle production. Feed additives like antibiotics or growth-promoting agents have become an integral part of ruminant production. The ionophores (e.g., monensin, lasalocid and sonilomycin) are an especially important group of feed additives. The ionophore monensin, a polyether antibiotic, is one of the most common additives used to modulate ruminant fermentation. Monensin selectively inhibits the growth of gram-positive bacteria; this inhibition reduces lactic acid production and methanogenesis in the rumen, increases the molar proportion of propionate and $\mathrm{N}$ retention (Goodrich et al., 1984). The positive responses of livestock to dietary monensin supplementation have been well-documented. Monensin improves feed conversion, particularly in high-grain diets.

However, Köhler et al. (2000) reported that certain anti-bacterial agents used as growth promoters might increase the horizontal transfer of virulence genes between bacteria, although this effect was not observed from monensin in vitro. Concerns about the use of in feed antibiotics have focused on the potential for antibiotic residue in animal products and the development of antibiotic-resistant pathogenic microbes. In Europe, resolution EU 1831/2003 has prohibited the use of sodium monensin since January of 2006. It is therefore necessary to develop alternative products that can replace antimicrobial feed additives.

Propolis extract has several anti-bacterial bioactivities that are related to flavonoids (Marcucci, 1995). Because propolis can inhibit the growth of gram positive bacteria, in might be a useful additive for modifying microbial fermentation in the rumen (Ozturk et al., 2010). However, we found no reports of studies that examined the effects of propolis extract on the quality of cattle meat. This work was carried out to study the effects of sodium monensin or propolis extract on the performance and carcass characteristics of feedlot-finished Nellore bulls. 


\section{MATERIAL AND METHODS}

\section{Animal management and sampling}

This study was carried out at the Experimental Farm of the State University of Maringá, Paraná (Brazil). It was approved by the Committee for Animal Production at the State University of Maringá (CIOMS/OMS, 1985) and followed the guiding principles of biomedical research on animals.

Thirty-three Nellore bulls were included in the study; they had an initial average age of 27 months and an initial liveweight of $400 \pm 2.33 \mathrm{~kg}$. The bulls were kept on pasture (mainly Cynodon spp., cv. Tifton 85) for 27 months. During the trial the bulls were kept in individual pens $\left(10 \mathrm{~m}^{2}\right.$ for each animal $)$ and fed twice a day. The bulls were weighed at the beginning of the experiment. Thereafter, they were weighed every 14 days following a 16-h fast (all feed was removed at 4 p.m. on the day prior to weighing). The total experimental period lasted 84 days, during which the bulls reached an average final liveweight of $484 \pm 6.76 \mathrm{~kg}$.

The bulls were given access to a diet that was formulated to allow beef cattle to gain $1.00 \mathrm{~kg} /$ day. The bulls were fed maize silage ad libitum in addition to a concentrate composed of cracked maize, soyabean meal, mineral salt, limestone and urea (Table 1). Water was given ad libitum. The amounts of concentrate offered daily to the animals were adjusted every 14 days after the bulls were weighed. The diet was weighed before delivery and adjusted daily to have leftovers of $5 \%$. The refusals were weighed daily. Dry matter (DM), crude protein $(\mathrm{CP})$, organic matter $(\mathrm{OM})$, ash, ether extract (EE), neutral detergent fibre (NDF) and acid detergent fibre (ADF) were determined according to the AOAC (1980) methods. Total carbohydrates $(\mathrm{TCH})$ were calculated using the equation: $\mathrm{TCH}=100-(\mathrm{CP} \%+\mathrm{EE} \%+$ ash\%) by Sniffen et al. (1992). Non-fibre carbohydrates (NFC) were determined to be the difference between TCH and NDF. Total digestive nutrients (TDN) were calculated by Kearl (1982).

Table 1. Chemical composition of diet ingredients (\%/DM) and composition of the diet

\begin{tabular}{lcccccccccc}
\hline \multirow{2}{*}{ Ingredients } & \multirow{2}{*}{$\mathrm{DM}^{1}$} & \multicolumn{9}{c}{ \% DM } \\
\cline { 3 - 10 } & & $\mathrm{CP}^{2}$ & $\mathrm{OM}^{3}$ & $\mathrm{Ash}$ & $\mathrm{EE}^{4}$ & $\mathrm{NDF}^{5}$ & $\mathrm{ADF}^{6}$ & $\mathrm{TDN}^{7}$ & $\mathrm{NFC}^{8}$ & Diet \% \\
\hline Maize silage & 32.1 & 8.15 & 96.5 & 3.46 & 2.06 & 48.4 & 25.6 & 86.3 & 38.0 & 52.0 \\
Maize & 88.9 & 8.93 & 99.1 & 0.95 & 3.50 & 17.7 & 4.40 & 86.6 & 68.9 & 42.9 \\
Soyabean meal & 88.6 & 49.0 & 93.7 & 6.26 & 1.30 & 13.7 & 5.97 & 43.5 & 29.8 & 4.30 \\
Mineral salt & 99.3 & & & & & & & & & 0.32 \\
Limestone & 99.3 & & & & & & & & & 0.19 \\
Urea & 97.5 & 282 & & & & & & & & 0.32 \\
Diet composition & 42.9 & 11.1 & 97.1 & 2.95 & 2.62 & 33.3 & 15.4 & 83.9 & 50.6 & 100 \\
\hline
\end{tabular}

${ }^{1}$ dry matter, ${ }^{2}$ crude protein, ${ }^{3}$ organic matter, ${ }^{4}$ ether extract, ${ }^{5}$ neutral detergent fibre, ${ }^{6}$ acid detergent fibre, ${ }^{7}$ total digestive nutrients, ${ }^{8}$ non-fibre carbohydrates 
Three treatments were examined on 11 bulls each: a control diet (CON), a diet with sodium monensin $(\mathrm{MON})$ and a diet with propolis extract (PRO). The propolis extract LLOS $(\mathrm{C} 1++)$ chartered by intellectual patrimonial number PI 0605768-3 was developed by the Pharmacy Laboratory (State University of Maringá). The propolis extract was prepared with alcohol according to Franco and Bueno (1999). The samples were stored in closed bottles at a temperature of $-5^{\circ} \mathrm{C}$, were diluted to between 50 to $96^{\circ} \mathrm{GL}$ with a fixed concentration of propolis extract. The extracts were dried by lyophilization for $24 \mathrm{~h}$. To prepare the concentrates, the extract was brought to ambient temperature and mixed with soyabean and maize. The product LLOSC $1++$ contains $0.054 \mathrm{mg} / \mathrm{g}$ of total flavonoids (chrysin). Monensin was produced by Elanco ${ }^{\circledR}$. The sodium monensin and propolis extract nuclei were mixed with the concentrate at the same time. The animals were fed $300 \mathrm{mg} /$ animal/day of sodium monensin and $35 \mathrm{~g} / \mathrm{animal} /$ day of propolis extract.

\section{Carcass characteristics}

The animals were slaughtered at a commercial slaughterhouse, according to the Brazilian industrial practices. The carcasses were chilled for $24 \mathrm{~h}$ at $4^{\circ} \mathrm{C}$. After it the right part of each carcass was used to determine the quantitative characteristics. After next $24 \mathrm{~h}$, Longissimus muscle (LM) samples were taken by a complete crosssection between the $12^{\text {th }}$ and $13^{\text {th }}$ ribs. The fat was discarded and the muscle portion was frozen at $20^{\circ} \mathrm{C}$ for further analysis. The following characteristics of carcass were examined:

hot carcass weight $(\mathrm{HCW})$ was determined after the slaughter and before the carcass was chilled,

hot carcass dressing (HCD): the percentage of individual animal dressing was defined as the hot carcass weight divided by the liveweight $14 \mathrm{~h}$ before slaughter,

carcass conformation (COF): Müller's (1980) point scale was used to determine carcass conformation; on this scale, the highest value indicates the best conformation. The carcass conformation was reported as superior, very good, good, regular, poor or inferior; ratings may also be reported as plus, mid and minus,

carcass length (CAL) was determined by measuring from the border of the pubis bone to the anterior side of the first rib; measurements were taken with a ribbon or a tape line,

leg length (LEL) was evaluated using a wooden compass with metallic edges that measures the distance from the anterior border of the pubis bone to a middle point on the tarsus bone,

cushion thickness (CUT) was determined using a wooden compass with metallic edges that measure the distance between the lateral face and the median at the superior part of the cushion. The cushion is flat muscle (Biceps femoris), 
fat thickness (FAT) was determined with a caliper averaging three points between the $12^{\text {th }}$ and the $13^{\text {th }}$ ribs on the Longissimus muscle (LM),

Longissimus muscle area (LMA) was measured with a tracing made on the right side of carcass; a transversal cut between the $12^{\text {th }}$ and $13^{\text {th }}$ ribs exposed the Longissimus muscle. Next, a compensating planimeter, an instrument that measures the area of irregularly shaped objects, was used to determine the area,

marbling (MAR): intramuscular fat was measured in the LM between the $12^{\text {th }}$ and $13^{\text {th }}$ ribs according to the Müller (1980) scores,

texture (TEX) was determined by the size of the fascicle (muscle "grain") and was evaluated subjectively with a point scale (Müller, 1980),

colour (COL): muscle colour was analysed after the carcass had been chilled for $24 \mathrm{~h}$. Coloration was evaluated according to a point scale (Müller, 1980) 30 min after a transversal section was made on the Longissimus muscle between the $12^{\text {th }}$ and $13^{\text {th }}$ ribs,

hydrogen potential $(\mathrm{pH})$ was determinate with a $\mathrm{pH}$ meter; the electrode was inserted in the muscle between the $12^{\text {th }}$ and $13^{\text {th }}$ ribs after the carcass was chilled for $24 \mathrm{~h}$.

To evaluate the post-mortem degradation of muscle proteins, the myofibrillar fragmentation index (MFI) was used according to the methods of Hopkins et al. (2000); the LM between the $12^{\text {th }}$ and $13^{\text {th }}$ ribs was examined. The homogenization was realized before the total protein determination and it was adjusted to the common concentration of the protein. A spectrophotometer (Thermo Scientific, GENESYS 10S Vis) was used to determine the absorbance and the absorbance value was then multiplied by the correction factor (200) according to the following equation: $\mathrm{MFI}=$ absorbance reading $\mathrm{x} 200$.

\section{Statistical analysis}

An one-way analysis of variance and Tukey's test were used (SAS, 2000). A significance was declared at $\mathrm{P}<0.05$.

\section{RESULTS AND DISCUSSION}

\section{Animal performance}

The final liveweight $(501 \mathrm{~kg})$, hot carcass weight $(275 \mathrm{~kg})$ and average daily gain $(1.17 \mathrm{~kg})$ of the bulls on the PRO diet were greater $(\mathrm{P}<0.05)$ than those of the bulls on the control diet (472, 259 and $0.87 \mathrm{~kg}$, respectively) or the MON diet (472, 259 and $0.87 \mathrm{~kg}$, respectively) (Tables 2 and 3). 
Table 2. Performance of Nellore bulls

\begin{tabular}{|c|c|c|c|c|c|}
\hline \multirow{2}{*}{ Parameters } & \multicolumn{3}{|c|}{ Diets } & \multirow{2}{*}{$\mathrm{SE}^{4}$} & \multirow{2}{*}{$\mathrm{P}$} \\
\hline & $\mathrm{CON}^{1}$ & $\mathrm{MON}^{2}$ & $\mathrm{PRO}^{3}$ & & \\
\hline No. of animals & 11 & 11 & 11 & & \\
\hline Initial liveweight, $\mathrm{kg}$ & 399 & 401 & 402 & 2.33 & NS \\
\hline Final weight, $\mathrm{kg}$ & $472^{\mathrm{b}}$ & $480^{\mathrm{b}}$ & $501^{\mathrm{a}}$ & 6.76 & 0.03 \\
\hline Average daily gain, $\mathrm{kg}$ & $0.87^{\mathrm{b}}$ & $0.94^{\mathrm{b}}$ & $1.17^{\mathrm{a}}$ & 0.06 & 0.02 \\
\hline Dry matter intake, $\mathrm{kg}$ /day & 9.51 & 9.14 & 9.41 & 0.32 & NS \\
\hline Dry matter intake/ liveweight, $\%$ & 1.99 & 1.90 & 1.90 & 0.06 & NS \\
\hline Dry matter conversion, $\mathrm{kg} / \mathrm{kg}$ gain & $10.9^{\mathrm{b}}$ & $9.72^{\mathrm{ab}}$ & $8.04^{\mathrm{a}}$ & 0.87 & 0.01 \\
\hline
\end{tabular}

${ }^{1}$ control, ${ }^{2}$ sodium monensin, ${ }^{3}$ propolis extract, ${ }^{4}$ standard error of the mean, NS - non significant, values with different letters in the same line differs significantly $(\mathrm{P}<0.05)$

The higher final liveweight, hot carcass weight and average daily gain of the bulls on the PRO diet may be due to several bioactivities of the propolis extract. For example, the propolis extract has anti-microbial, anti-inflammatory, anti-oxidant, and anti-viral properties (Hegazi et al., 2000). In ruminants propolis has been used in the modification of rumen fermentation (Broudiscou et al., 2000; Ozturk et al., 2010). Pires do Prado et al. (2010) reported increases in total and intestinal digestibility, higher concentration of digestible energy and apparent increase in the flow of intestinal protein based diets with forage for buffalo fed with LLOSB3 LLOSC1 products based on propolis.

The average daily gain $(1.00 \mathrm{~kg})$ could be considered low for feedlot-finished bulls on an energy-dense diet (Abrahão et al., 2005; Kazama et al., 2008; Maggioni et al., 2009a; Rotta et al., 2009b). However, Nellore animals usually present an average daily gain of $0.90 \mathrm{~kg}$ to $1.20 \mathrm{~kg}$ (D'Olveira et al., 1997).

Propolis extract could be used as an alternative additive that replaces sodium monensin and increases an animal's weight gain. In Brazil, the use of sodium monensin is permitted; however, Brazil exports around $25.0 \%$ of its production to Europe, the United States and Asia, where the use of sodium monensin is regulated or banned. Sodium monensin should therefore be replaced with another product that does not have the same negative effects. Propolis extract is a natural product that may be a safe alternative.

The dry matter intake ( $\mathrm{kg} / \mathrm{day}$ or $\mathrm{kg} / 100 \mathrm{~kg}$ of body weight) was similar $(\mathrm{P}>0.05)$ among animals on the three diets. However, the daily dry matter intake was low (9.35 kg/day or $1.93 \mathrm{~kg} / 100 \mathrm{~kg}$ body weight) for bulls finished in a feedlot. This low intake was influenced by the animal breed. Nellore animals have a low average daily gain, and feed intake is also low (D'Oliveira et al., 1997).

Dry matter conversion ( $\mathrm{kg}$ dry matter $/ \mathrm{kg}$ average daily gain) was better $(\mathrm{P}<0.05)$ for animals on the PRO diet (8.40) than for those on the CON (10.9) or MON (9.72) diets. The better dry matter conversion for the bulls on the PRO diet may be due to the bioactivities of the propolis extract, particularly the antibacterial action that is related to flavonoids (Marcucci, 1995). 
Sodium monensin and propolis extractreduce the gram-positive microorganisms responsible for methane production in the rumen. The inclusion of these products therefore also reduces methane emissions that have a greenhouse effect (Stradiotti et al., 2004). Broudiscou et al. (2000) studied the effects of thirteen dry plant extracts with high flavonoid levels on fermentation and methanogenesis in cultures of rumen microorganisms and observed that propolis extract increased the propionate production (energy source) by $10.3 \%$ and reduced the population of the microorganisms. These authors observed that propolis extract did not alter dry matter intake, $\mathrm{pH}$, ammonia levels, or microbial protein in the rumen liquid of cattle fed with roughage. However, propolis extract hindered desamination by rumen microorganisms. This finding suggests that ammonia levels may be reduced in the rumen of animals on diets that have elevated protein degradable/ fermentation carbohydrates.

\section{Carcass characteristics}

The carcass dressing was similar $(\mathrm{P}>0.05)$ among treatments; the mean dressing percentage was $54.7 \%$. According to Prado et al. (2008 b,c), carcass dressing can be influenced by inherent oscillation factors such as genotype, rumen fill, fasting period and transportation; it can also be influenced by the slaughter location and cleaning process.

Hot carcass weight was higher $(\mathrm{P}<0.05)$ for animals on the PRO $(275 \mathrm{~kg})$ diet than those on the CON (259 kg) and MON (259 kg) diets. Animals that received the PRO treatment were slaughtered at a higher weight, so the hot carcass weight was higher for the animals on the PRO diet.

Characteristics such as carcass conformation, carcass length, leg length, cushion thickness, Longissimus muscle area, Longissimus muscle area/100 kg liveweight, fat thickness, colour, texture, marbling, $\mathrm{pH}$ and fragmentation index were not influenced by the diets (Table 3). Carcass conformation is an important characteristic in the commercial cattle industry in Brazil. Carcasses were classified as very good on the Müller (1980) scale, so these animals did not present any problems for commercial beef production.

The carcass length, leg length and cushion thickness varied little among the animals on different diets and the values were close to those found by others researchers (Prado et al., 2008a; Rotta et al., 2009b).

The Longissimus muscle area shows carcass muscle development and is therefore directly correlated to hot carcass weight. The iso-proteic and iso-energetic diet used in this experiment had little influence on this characteristic. The bulls presented good muscularity and the muscle area values were close to those found by Prado et al. (2008a). 
Table 3. Carcass characteristics of Nellore bulls finished in a feedlot

\begin{tabular}{|c|c|c|c|c|c|}
\hline \multirow{2}{*}{ Parameters } & \multicolumn{3}{|c|}{ Treatments } & \multirow[b]{2}{*}{$\mathrm{SE}^{4}$} & \multirow[b]{2}{*}{$\mathrm{P}<\mathrm{F}$} \\
\hline & $\mathrm{CON}^{1}$ & $\mathrm{MON}^{2}$ & $\mathrm{PRO}^{3}$ & & \\
\hline $\mathrm{N}$ & 11 & 11 & 11 & & \\
\hline Hot carcass weight, $\mathrm{kg}$ & $259^{\mathrm{b}}$ & $259^{\mathrm{b}}$ & $275^{\mathrm{a}}$ & 3.94 & 0.01 \\
\hline Carcass dressing, \% & 54.9 & 53.9 & 55.0 & 1.98 & NS \\
\hline Conformation, points & 14.1 & 14.5 & 14.2 & 0.40 & NS \\
\hline Carcass length, $\mathrm{cm}$ & 128 & 130 & 129 & 0.97 & NS \\
\hline Leg length, $\mathrm{cm}$ & 78.3 & 77.3 & 78.2 & 0.54 & NS \\
\hline Cushion thickness, $\mathrm{cm}$ & 25.3 & 25.3 & 25.3 & 0.39 & NS \\
\hline Longissimus muscle area, $\mathrm{cm}^{2}$ & 67.5 & 68.2 & 70.4 & 2.01 & NS \\
\hline Longissimus muscle area ${ }^{5}$ & 26.0 & 26.3 & 25.6 & 0.71 & NS \\
\hline Fat thickness, mm & 3.59 & 3.45 & 2.98 & 0.32 & NS \\
\hline Colour, points & 3.63 & 3.81 & 3.54 & 0.19 & NS \\
\hline Texture, points & 3.27 & 3.54 & 3.27 & 0.19 & NS \\
\hline Marbling, points & 5.27 & 5.18 & 5.18 & 0.34 & NS \\
\hline $\mathrm{pH}$ & 5.79 & 5.81 & 5.77 & 0.03 & NS \\
\hline Fragmentation index & 81.7 & 82.3 & 82.0 & 0.96 & NS \\
\hline
\end{tabular}

The Longissimus muscle colour ranged from red to slightly dark red (Müller, 1980), which is considered to be good. The colour of meat is an important commercial characteristic that influences consumer behaviour. Colour can be affected by age, gender (Rotta et al., 2009b), nutrition (Prado et al., 2008a) and genetic group (Prado et al., 2008b,c, 2009a,b,c; Rotta et al., 2009a). Older animals have a higher concentration of myoglobin and therefore darker meat. Bulls can also have darker meat because of high $\mathrm{pH}$ levels.

Texture is classified by granulation on the Longissimus muscle surface. In this study, the Longissimus muscle texture was 3.36 points and could be defined as slightly coarse or coarse. The average $\mathrm{pH}$ (5.70) after $24 \mathrm{~h}$ of chilling reflects a meat of good quality; $\mathrm{pH}$ values above 6.00 increase water retention and result in meat that is dark, firm and dry. The various dietary treatments did not affect $(\mathrm{P}>0.05)$ the myofibrillar fragmentation index (MFI). The average MFI was $82.0 \%$. According to Culler et al. (1978) and Hopkins et al. (2000), a value above $60.0 \%$ indicates a soft meat.

\section{CONCLUSIONS}

The addition of propolis extract to the diet increased weight gain and improved feed conversion. These effects were not observed with sodium monensin. These additives did not alter the carcass characteristics. Propolis extract is a natural product that does not affect human health, and could be a useful addition to ruminant diets. 


\section{REFERENCES}

Abrahão J.J.S., Prado I.N., Perotto D., Moletta J.L., 2005. Effects of replacing maize with increasing levels of cassava starch by-products on carcass characteristics and meat for young bulls. Braz. J. Anim. Sci. 34, 1640-1650

AOAC, 1980. Association of Official Analytical Chemists, Official Methods of Analysis. 14 ${ }^{\text {th }}$ Edition. Washington, DC

Aricetti J.A., Rotta P.P., Prado R.M., Perotto D., Moletta J.L., Matsushita M., Prado I.N., 2008. Carcass characteristics, chemical composition and fatty acid profile of Longissimus muscle of bulls and steers finished in a pasture system. Asian-Austr. J. Anim. Sci. 21, 1441-1448

Broudiscou L.P., Papon Y., Broudiscou A.F., 2000. Effects of dry plant extracts on fermentation and methanogenesis in continuous culture of rumen microbes. Anim. Feed Sci. Tech. 87, 263-277

CIOMS/OMS, 1985. Council for International Organizations of Medical Services. WHO Distribuition and sales service, 1211 Geneva 27 (Switzerland). International Guiding Principles for Biomedical Research Involving Animals

Culler R.D., Parrish F.C., Smith G.C., Cross H.R., 1978. Relationship of myofibril fragmentation index to certain chemical, physical and sensory characteristics of bovine Longissimus muscle. J. Food Sci. 43, 1177-1180

D’Oliveira P.S., Prado I.N., Santos G.T., Zeoula L.M., Damasceno J.C., Martins E.N., Sakaguti E.S., 1997. Effect of replacing soybean meal with canola meal on the performance of Nellore feedlot heifers. Braz. J. Anim. Sci. 26, 568-574

Franco S.L., Bueno J.H.F., 1999. Optimization of extraction process of propolis. Infarma 11, 48-51

Goodrich R.D., Garrett J.E., Gast D.R., Kirick M.A., Larson D.A., Meiske J.C., 1984. Influence of monensin on the performance of cattle. J. Anim. Sci. 58, 1484-1498

Hegazi A.G., Hady F.K.A.E., Allah F.A.M.A., 2000. Chemical composition and antimicrobial activity of European propolis. Z. Naturforsch. C 55, 70-75

Hopkins D.L., Littlefield P.J., Thompson J.M., 2000. A research note on factors affecting the determination of myofibrillar fragmentation. Meat Sci. 56, 19-22

Kazama R., Zeoula L.M., Prado I.N., Silva D.C., Ducatti T., Matsushita M., 2008. Quantitative and qualitative carcass characteristics of heifers fed different energy sources on a cottonseed hulls and soybean hulls based diet. Braz. J. Anim. Sci. 37, 350-357

Kearl L.C., 1982. Nutrient Requirements of Ruminant in Development Countries. Logan: International Feedstuffs Institute, Utah Agricultural Experiment Station, Utah State University, Logan, pp. 271

Köhler B., Karch H., Schmidt K., 2000. Antibacterials that are used as growth promoters in animal husbandry can affect the release of Shiga-toxin-2-converting bacteriophages and Shia toxin 2 from Escherichia coli strains. Microbiology 146, 1085-1090

Maggioni D., Marques J.A., Perotto D., Rotta P.P., Ducatti T., Matsushita M., Silva R.R., Prado I.N., 2009. Bermuda grass hay or sorghum silage with or without yeast addition on performance and carcass characteristics of crossbred young bulls finished in feedlot. Asian-Austr. J. Anim. Sci. 22, 206-215

Marcucci M.C., 1995. Propolis: chemical composition, biological properties and therapeutic activity. Apidolioge 26, 83-99

Müller L., 1980. Standards for Carcass Evaluation and Carcass of Steers Contest 1. Santa Maria (RS, Imprensa Universitária), UFSM

Ozturk H., Pekcan M., Sireli M., Fidanci U.R., 2010. Effects of propolis on in vitro rumen microbial fermentation. Ankara Üniv. Vet. Fak. Derg. 57, 217-221 
Pires do Prado O.P.P., Zeoula L.M., Moura L.P.P., Franco S.L., Prado I.N., Jacobi G., 2010. Effect of propolis and sodium monensin addition on digestibility and ruminal characteristics of buffaloes fed diet based on roughage. R. Bras. Zootec. 39, 2055-2065

Prado I.N., Ito R.H., Prado J.M., Prado I.M., Rotta P.P., Matsushita M., Visentainer J.V., Silva R.R., 2008a. The influence of dietary soyabean and linseed on the chemical composition and fatty acid profile of the Longissimus muscle of feedlot-finished bulls. J. Anim. Feed Sci. 17, 307-317

Prado I.N., Oliveira A.N., Rotta P.P., Perotto D., Prado R.M., Silva R.R., Souza N.E., Moletta J.L., 2009c. Chemical and fatty acid composition of Longissimus muscle of crossbred bulls finished in feedlot. Asian-Austr. J. Anim. Sci. 22, 1054-1059

Prado I.N., Prado R.M., Rotta P.P., Visentainer J.V., Moletta J.L., Perotto, D., 2008b. Carcass characteristics and chemical composition of the Longissimus muscle of crossbred bulls (Bos taurus indicus vs Bos taurus taurus) finished in feedlot. J. Anim. Feed Sci. 17, 295-306

Prado I.N., Rotta P.P., Prado R.M., Visentainer J.V., Moletta J.L., Perotto, D., 2008c. Carcass characteristics and chemical composition of the Longissimus muscle of Purunã and $1 / 2$ Puruna vs. $1 / 2$ Canchin bulls. Asian-Austr. J. Anim. Sci. 21, 1296-1302

Prado J.M., Prado I.N., Visentainer J.V., Rotta P.P, Perotto D., Moletta J.L., Prado I.M., Ducatti T., 2009a. The effect of breed on chemical composition and fatty acid profile of the Longissimus dorsi muscle of Brazilian beef cattle. J. Anim. Feed Sci. 18, 231-240

Prado R.M., Prado I.N., Marques J.A., Rotta P.P., Visentainer J.V., Silva R.R., Souza N.E., 2009b. Meat quality of the Longissimus muscle of bulls and steers (1/2 Nellore vs $1 / 2$ Simenthal) finished in feedlot. J. Anim. Feed Sci. 18, 221-230

Rotta P.P., Prado I.N., Prado R.M., Moletta J.L., Silva R.R., Perotto D., 2009a. Carcass characteristics and chemical composition of the Longissimus muscle of Nellore, Caracu and Holstein-friesian bulls finished in a feedlot. Asian-Austr. J. Anim. Sci. 22, 598-604

Rotta P.P., Prado R.M., Prado I.N., Valero M.V., Visenatiner J.V. Silva R.R., 2009b. The effects of genetic groups, nutrition, finishing systems and gender of Brazilian cattle on carcass characteristics and beef composition and apperance: a review. Asian-Austr. J. Anim. Sci. 22 (12), 1718-1734

SAS, 2000. User's Guide: Statistics Sas Institute SAS/STAT ${ }^{\circ}, 8.1 .4^{\text {th }}$ Edition. Cary, NC

Sniffen C.J., O’Connor J.D., Van Soest P.J., Fox D.G., Russell J.B., 1992. A net carbohydrate and protein system for evaluating cattle diets: 11. Carbohydrate and protein availability. J. Anim. Sci. 70, 3562-3577

Stradiotti Jr. D., Queiroz A.C., Lana R.P., Pacheco C.G., Camardelli M.M.L., Eifert E.C., Nunes P.M.M., Oliveira M.V.M., 2004. Effect of the propolis on the in vitro fermentation of different feedstuffs by the technique of gas production. Braz. J. Anim. Sci. 33, 1093-1099 